\title{
Karakter Morfologis dan Molekular Macrobrachium spp. dari Sungai Opak Daerah Istimewa Yogyakarta
}

\author{
TRIJOKO $^{1}$, NIKEN SATUTI NUR HANDAYANI ${ }^{2}$, ANITA WIDIANAWATI $^{3}$, RURY \\ EPRILURAHMAN $^{1}$
}

\author{
${ }^{1}$ Laboratorium Sistematika Hewan, Fakultas Biologi, Universitas Gadjah Mada \\ Jl. Teknika Selatan, Sekip Utara, Yogyakarta 55281 \\ email: rurybiougm@ugm.ac.id \\ ${ }^{2}$ Laboratorium Genetika, Fakultas Biologi, Universitas Gadjah Mada \\ Jl. Teknika Selatan, Sekip Utara, Yogyakarta 55281 \\ ${ }^{3}$ Fakultas Biologi, Universitas Gadjah Mada \\ Jl. Teknika Selatan, Sekip Utara, Yogyakarta 55281
}

\begin{abstract}
Several rivers flow across Daerah Istimewa Yogyakarta (DIY) includes Opak River which it's upstream located on Merapi Volcano area. The river has a lot of biological resources, includes prawns. Freshwater prawns (Macrobrachium spp.) has important role in maintaining the balance of freshwater ecosystems. The purpose of this research was to determine species diversity of Macrobrachium spp. and to understand the morphological and molecular characters of them. Phenetic similarity was analyzed using 74 morphological characters, ISSR1 and ISSR3 primers. The results were analyzed using a program MVSP 3.1 (Multi- Variate Statistical Package) to obtain a dendogram that showed both intra-and interspecies similarity of Macrobrachium spp. Six species of Genus Macrobrachium were identified, they are Macrobrachium pilimanus, M. sintangense, M. lanchesteri, M. cowlesi, $M$. latidactylus, and M. equidens. Both morphological and molecular analyses show two major clusters with the similarity of $55.6 \%$ for morphology and $21.52 \%$ for molecular. Based on morphological and molecular characters analysis, we concluded that phenetic similarity of Macrobrachium spp. in Opak River was affected by the morphological structure of the second pereiopod, habitat type, size and number of eggs, as well as the type of larval development.
\end{abstract}

Keywords: characters, Macrobrachium, molecular, morphology, Opak River

\section{PENDAHULUAN}

Macrobrachium spp. (udang air tawar atau udang sungai) merupakan salah satu komoditas perikanan air tawar yang memiliki nilai ekonomi tinggi. Menurut Wowor et al. (2009) dan Taufik (2011), udang air tawar mempunyai peranan penting dalam menjaga keseimbangan ekosistem. Salah satunya sebagai komponen mata rantai makanan. Keberadaan berbagai jenis udang air tawar dalam suatu sungai dapat digunakan sebagai indikator kualitas suatu perairan, serta dapat meningkatkan kualitas kondisi lingkungan perairan sungai tersebut. Pelestarian udang air tawar penting dilakukan agar keseimbangan ekosistem dapat dipertahankan.

Sungai Opak merupakan salah satu sungai di DIY yang mempunyai Daerah Aliran Sungai
(DAS) berhulu di lereng Gunung Merapi. DAS Sungai Opak mengalir ke arah selatan melewati daerah Kalasan dan memasuki daerah Imogiri. Sungai ini sebagai tempat muara sungai-sungai kecil dan menengah yang ada di sekitarnya seperti Sungai Kuning, Gajahwong, dan Code (Trijoko \& Pranoto, 2006). Pada tahun 2010, Gunung Merapi mengalami erupsi yang cukup besar. Erupsi tersebut berdampak pada perairan di Sungai Opak terutama ketika hujan. Debit air dari hulu lereng merapi akan membawa material vulkanik berupa lahar dingin yang terdiri dari pasir, kerikil, dan batu yang tentunya akan berpengaruh terhadap perubahan ekosistem sungai. Hal tersebut dikhawatirkan dapat menurunkan keragaman genetik dan populasi di alam. 
Penelitian ini menggunakan penanda molekular ISSR. Penanda molekular merupakan suatu teknik yang dapat digunakan untuk analisis variasi genetik antar spesies maupun intra spesies. ISSR (Inter-simple Sequence Repeat) merupakan PCR (Polymerase Chain Reaction)-based marker, tidak memerlukan informasi tentang sekuen genom yang akan diuji, dan menggunakan primer mikrosatelit tunggal dalam reaksi PCR dengan target multiple-locus genomik. Penelitian mengenai karakterisasi morfologis dan molekular Macrobrachium spp. di Sungai Opak DIY belum pernah dilakukan sehingga penelitian ini perlu dilakukan untuk mengetahui keanekaragaman spesies udang Macrobrachium di Sungai Opak DIY serta diversitas genetik baik intra maupun interspesiesnya.

Penelitian ini bertujuan untuk mengetahui keanekaragaman jenis udang air tawar (Macrobrachium spp.) di Sungai Opak DIY setelah erupsi Merapi tahun 2010, serta mengetahui karakter morfologis dan molekular udang Macrobrachium spp.

\section{METODE}

Pengambilan Sampel Udang. Sampling dilakukan pada bulan Juni-Oktober 2013 di sepanjang Sungai Opak yang memiliki panjang kurang lebih $60 \mathrm{~km}$ dari hulu (di Desa Cangkringan, Sleman) sampai muara sungai (di daerah Samas, Bantul). Pengambilan sampel dibagi menjadi empat stasiun yaitu: Opak Hulu (OHu), Opak Tengah (OTe), Opak Hilir (OHi), dan Opak Muara (OMu). Pada tiga stasiun pertama dibuat masing-masing 5 titik sampling (TS), sedangkan stasiun Opak Muara hanya dibuat 3 titik sampling.

Panjang sungai yang disampling pada tiap TS lebih kurang $500 \mathrm{~m}$. Pengambilan sampel dilakukan secara random purposif sampling. Pengambilan sampel di sungai bagian huluhilir dengan menggunakan seser kecil (ukuran $20 \times 25 \mathrm{~cm}$ ) dan seser besar (ukuran $40 \times 20$ $\mathrm{cm}$ ) dengan diameter mata jaring $\pm 1 \mathrm{~mm}$. Sementara pengambilan sampel di sungai bagian muara dengan menggunakan jala tebar. Pengambilan sampel dilakukan dua periode yaitu pagi/ siang hari dan malam hari.
Identifikasi dan Verifikasi Jenis Udang. Identifikasi dilakukan dengan menggunakan kunci identifikasi Macrobrachium dan buku identifikasi udang yang disusun oleh Eguia et al. (2009). Identifikasi dilakukan dengan cara mengamati secara langsung bagian-bagian tubuh udang yang dapat dilihat oleh mata, serta pengamatan dengan menggunakan mikroskop stereo atau mikroskop digital untuk melihat struktur bagian tubuh mikroskopis udang yang penting untuk identifikasi. Udang yang telah teridentifikasi kemudian dibawa ke Laboratorium Zoologi, Puslit Biologi, LIPI untuk verifikasi atau memastikan hasil identifikasi jenis udang.

Penentuan Karakter Morfologis. Karakter-karakter morfologis diperoleh dengan melakukan pengamatan sifat-sifat fenotip yang dimiliki oleh setiap jenis Udang Macrobrachium yang diperoleh. Data yang diambil meliputi data morfologis, morfometrik, dan meristik lainnya. Data morfologis yang diambil meliputi karakterkarakter diagnostik udang. Data morfometrik udang diperoleh dengan cara mengukur bagian-bagian tubuh udang dengan menggunakan kaliper dengan ketelitian 0,01 mm. Data meristik diperoleh dengan cara menghitung jumlah bagian tubuh tertentu dari udang tersebut.

Karakterisasi Molekular. Ekstraksi DNA udang dilakukan dengan mengikuti petunjuk GeneJET Genomic DNA Isolation Kit (FERMENTAS). Amplifikasi DNA menggunakan primer ISSR1 dan ISSR3 dilakukan berdasarkan Protokol Dream Taq Master Mix PCR. Amplifikasi DNA dilakukan dengan mesin PCR menggunakan tiga tahapan standar yaitu denaturation pada suhu $94^{\circ} \mathrm{C}$, annealing pada suhu $50^{\circ} \mathrm{C}$ dan extension pada suhu $72^{\circ} \mathrm{C}$. PCR tersebut dilakukan sebanyak 45 siklus. Hasil PCR diamati dengan elektroforesis menggunakan agarose $2 \%$, tegangan 50 volt, dalam buffer TBE (Tris Borat EDTA) dan digunakan DNA ladder 100 bp atau $1 \mathrm{~kb}$ sebagai pembanding.

Analisis Hasil. Karakter-karakter morfologis dan pita-pita DNA hasil elektroforesis diubah menjadi matriks biner (01). Jika sifat karakter morfologik yang diamati 
ada atau dimiliki oleh suatu individu, sifat tersebut ditulis dengan angka 1. Sifat yang tidak muncul atau tidak dimiliki oleh suatu individu ditulis dengan angka 0 . Karakter morfometrik yang bersifat kuantitatif diubah ke dalam bentuk kualitatif. Nilai yang berada di dalam kisaran deviasi ditulis dengan angka 1 , sedangkan yang berada di luar deviasi ditulis dengan angka 0 . Fragmen DNA yang tampak pada foto gel hasil elektroforesis diberi skor 1 sedangkan bila tidak ada diberi skor 0. Matrik data dibuat dengan program Ms. Excel 2007. Analisis clustering menggunakan metode
UPGMA (Unweighted Pair Group with Arithmetic Average) dengan program MVSP 3.2 (Multi Variate Statistical Package).

\section{HASIL}

Identifikasi Jenis Udang. Total individu udang yang teridentifikasi sebanyak 266 individu. Enam jenis udang dari genus Macrobrachium yang ditemukan di Sungai Opak adalah $M$. cowlesi, M. equidens, $M$. lanchesteri, M. latidactylus, M. pilimanus, dan M. sintangense. Sebaran jenis di tiap lokasi sampling dapat dilihat di Tabel 1.

Tabel 1. Daftar Jenis Udang Macrobrachium spp. yang ditemukan di Sungai Opak DIY

\begin{tabular}{|c|c|c|c|c|c|c|c|c|c|c|c|c|c|}
\hline \multicolumn{2}{|l|}{ Jenis Udang } & \multicolumn{2}{|c|}{$\begin{array}{c}\text { M. } \\
\text { pilimanus }\end{array}$} & \multicolumn{2}{|c|}{$\begin{array}{c}M . \\
\text { sintangense }\end{array}$} & \multicolumn{2}{|c|}{ M.lanchesteri } & \multicolumn{2}{|c|}{ M.cowlesi } & \multicolumn{2}{|c|}{ M.latidactylus } & \multicolumn{2}{|c|}{$\begin{array}{c}M . \\
\text { equidens }\end{array}$} \\
\hline Stasiun & $\mathrm{TS}$ & $\mathrm{S}$ & $\mathrm{M}$ & $\mathrm{S}$ & $\mathrm{M}$ & $\mathrm{S}$ & $\mathrm{M}$ & $\mathrm{S}$ & M & $\mathrm{S}$ & M & $\mathrm{S}$ & $\mathrm{M}$ \\
\hline \multirow{5}{*}{$\begin{array}{l}\text { Hulu } \\
\text { (532-151 m dpl) }\end{array}$} & 1 & - & 5 & - & - & - & - & - & - & - & - & - & - \\
\hline & 2 & 10 & 32 & 1 & - & - & - & - & - & - & - & - & - \\
\hline & 3 & 9 & 18 & - & - & - & - & - & - & - & - & - & - \\
\hline & 4 & - & - & - & 3 & - & - & - & - & - & - & - & - \\
\hline & 5 & - & - & 2 & 7 & - & - & - & - & - & - & - & - \\
\hline \multirow{5}{*}{$\begin{array}{c}\text { Tengah } \\
(137-70 \mathrm{~m} \mathrm{dpl})\end{array}$} & 1 & - & & - & 5 & - & - & - & - & - & - & - & - \\
\hline & 2 & - & - & 2 & 19 & - & - & - & - & - & - & - & - \\
\hline & 3 & - & - & 11 & 7 & - & - & - & - & - & - & - & - \\
\hline & 4 & - & - & 7 & 35 & - & - & - & - & - & - & - & - \\
\hline & 5 & - & - & 7 & 13 & - & - & - & - & - & - & - & - \\
\hline \multirow{5}{*}{$\begin{array}{c}\text { Hilir } \\
\text { (74-22 m dpl) }\end{array}$} & 1 & - & 1 & - & 17 & - & 1 & - & - & - & - & - & - \\
\hline & 2 & - & - & 1 & 20 & - & - & - & - & - & - & - & - \\
\hline & 3 & - & - & - & 11 & - & - & - & - & - & - & - & - \\
\hline & 4 & - & - & 1 & 13 & - & - & - & 1 & - & - & - & - \\
\hline & 5 & - & - & - & 1 & - & - & 1 & - & - & - & - & - \\
\hline \multirow{3}{*}{$\begin{array}{c}\text { Muara } \\
\text { (22-20 m dpl) }\end{array}$} & 1 & - & - & - & - & - & - & - & - & - & 3 & - & 1 \\
\hline & 2 & - & - & - & - & - & - & - & - & - & 1 & - & 2 \\
\hline & 3 & - & - & - & - & - & - & - & - & - & - & - & 1 \\
\hline
\end{tabular}

Keterangan : $\mathrm{TS}=$ Titik Sampling, $\mathrm{S}=$ Siang, $\mathrm{M}=$ Malam

Hasil Analisis Karakter Morfologis. Analisis similaritas morfologis baik inter maupun intra spesies disajikan dalam bentuk dendogram (Gambar 1). Dendogram similaritas untuk kelompok Macrobrachium spp. dari Sungai Opak berdasarkan 74 karakter morfologis membentuk 2 cluster besar yaitu cluster $\mathrm{B}$ dan cluster $\mathrm{C}$ dengan koefisien 0,556 (kesamaan 55,6\%). 


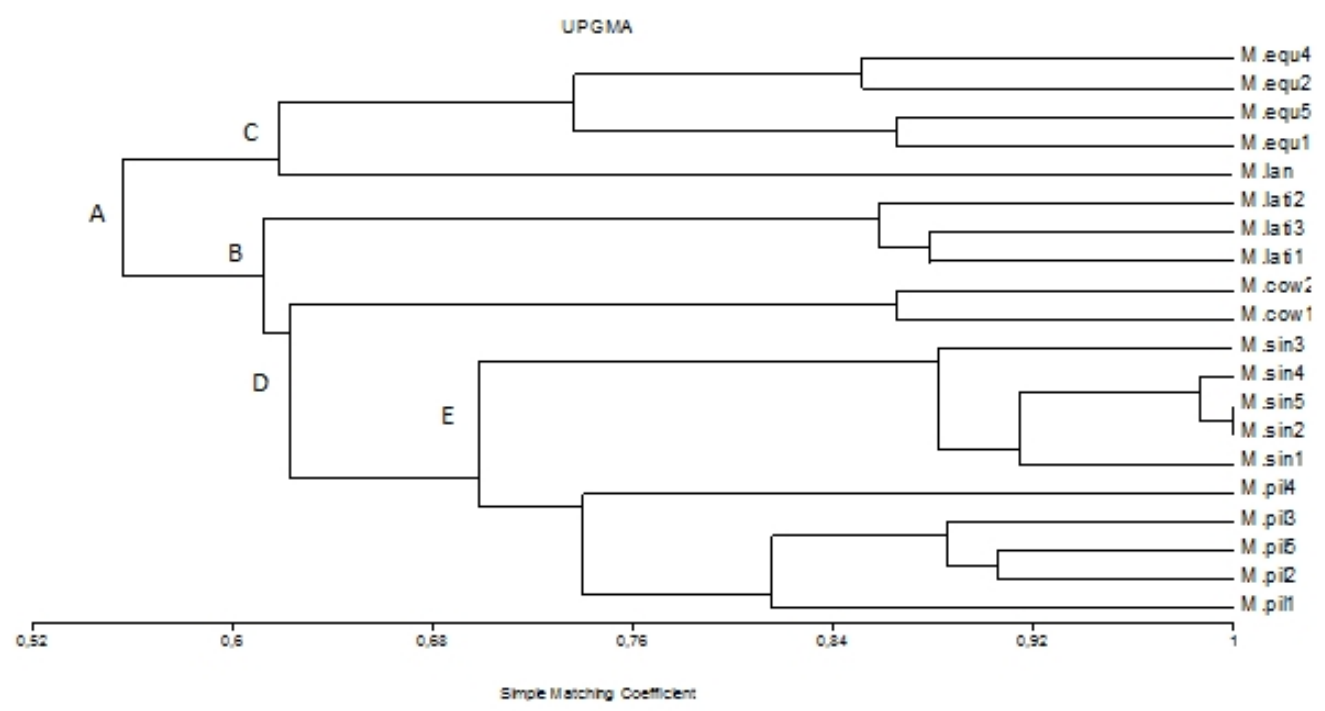

Gambar 1. Dendogram similaritas fenetik karakter morfologis intraspesies dan interspesies Macrobrachium spp. dariSungai Opak DIY (Ket: $M$. pil=M. pilimanus, M.sin=M. sintangense, M. cow $=M$. cowlesi, $M$. lati $=M$. latidactylus, $M$. lan=M. lanchesteri, $M$. equ=M. equidens)

Hasil Analisis Karakter Molekular. Pengamatan variasi genetik udang Macrobrachium spp. menggunakan penanda ISSR dilakukan berdasarkan ada atau tidaknya pita DNA hasil amplifikasi pada gel elektroforesis. Pengamatan terhadap pola pita DNA pada gel hasil elektroforesis menunjukkan bahwa setiap jenis primer menghasilkan pita DNA yang berbeda. Hasil analisis molekular untuk Macrobrachium spp dari Sungai Opak disajikan dalam bentuk tabel dan gambar. Tabel 2 dan Tabel 3 menunjukkan hasil penghitungan lokus berdasarkan primer ISSR1 dan ISSR3.

Tabel 2. Jenis dan Jumlah lokus yang dihasilkan oleh primer ISSR1 dan ISSR3

\begin{tabular}{clccc}
\hline Primer & Sekuens 5'-3 & $\begin{array}{c}\text { Total } \\
\text { Lokus }\end{array}$ & $\begin{array}{c}\text { Jumlah } \\
\text { Lokus } \\
\text { Polimorfik }\end{array}$ & $\begin{array}{c}\text { Persentase } \\
\text { Polimorfik } \\
(\%)\end{array}$ \\
\hline ISSR1 & AGAGAGAGAGAGAGAGT & 18 & 18 & $100 \%$ \\
\hline ISSR3 & GAGAGAGAGAGAGAGAT & 20 & 20 & $100 \%$ \\
\hline \multicolumn{2}{c}{ Jumlah } & 38 & 38 & \\
\hline & Rata-rata & 19 & 19 & $100 \%$ \\
\hline
\end{tabular}

Tabel 3. Jenis dan Jumlah lokus intraspesies yang dihasilkan dari tiap-tiap jenis Macrobrachium spp. oleh primer ISSR1 \& ISSR3

\begin{tabular}{lcccc}
\hline \multicolumn{1}{c}{ Spesies/ Jenis } & $\begin{array}{c}\text { Total } \\
\text { Lokus }\end{array}$ & $\begin{array}{c}\text { Jumlah } \\
\text { Lokus } \\
\text { Polimorfik }\end{array}$ & $\begin{array}{c}\text { Jumlah } \\
\text { Lokus } \\
\text { Monomorfik }\end{array}$ & $\begin{array}{c}\text { Persentase } \\
\text { Polimorfik } \\
(\%)\end{array}$ \\
\hline M. pilimanus & 10 & 7 & 3 & $70 \%$ \\
\hline M. cowlesi & 9 & 4 & 5 & $44,44 \%$ \\
\hline M. sintangense & 12 & 7 & 5 & $58,33 \%$ \\
\hline M. latidactylus & 13 & 7 & 6 & $53,85 \%$ \\
\hline M. equidens & 10 & 6 & 4 & $60 \%$ \\
\hline M. lanchesteri & 8 & - & - & - \\
\hline Jumlah & 62 & 31 & 23 & $57,32 \%$ \\
\hline Rata-rata & 10,33 & 6,2 & 4,6 & \\
\hline
\end{tabular}




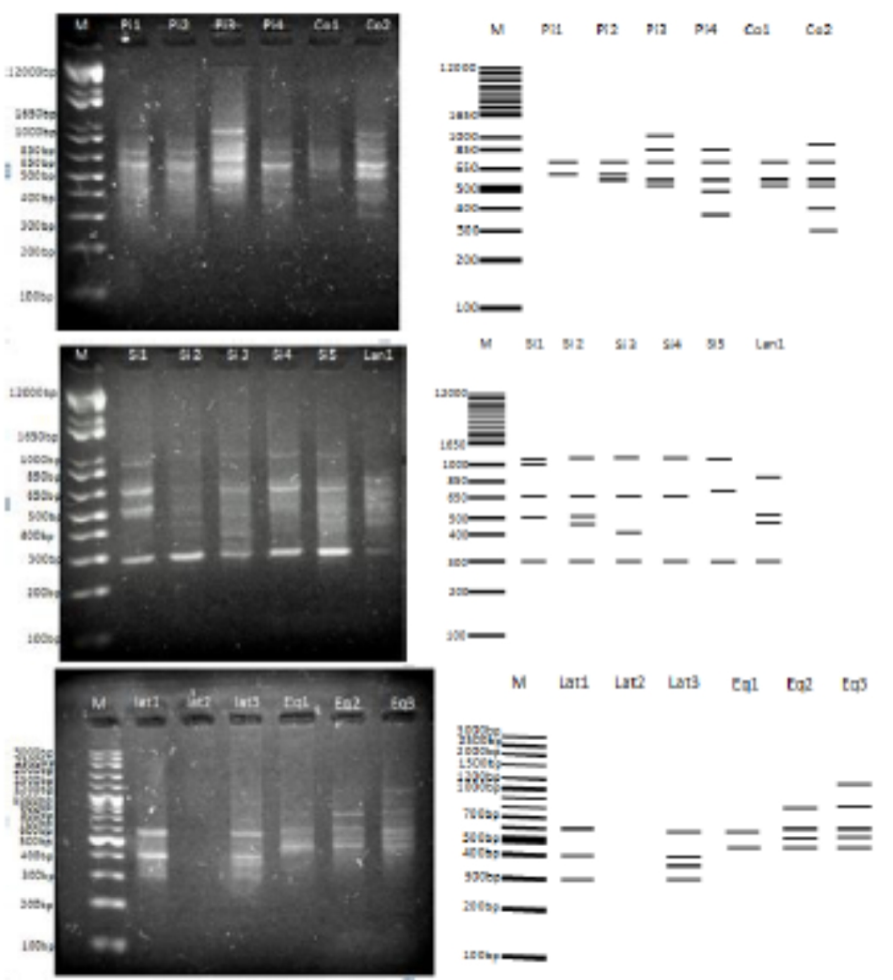

Gambar 3. Hasil elektroforesis sampel DNA Macrobrachium spp. yang diamplifikasi dengan primer ISSR1 (Keterangan: $\mathrm{M}=$ marker, $\mathrm{Pi}=M$. pilimanus, $\mathrm{Co}=M$. cowlesi, $\mathrm{Si}=M$. sintangense, $\mathrm{Lan}=M$. lanchesteri, Lat $=$ M. latidactylus, $\mathrm{Eq}=$ M. equidens).

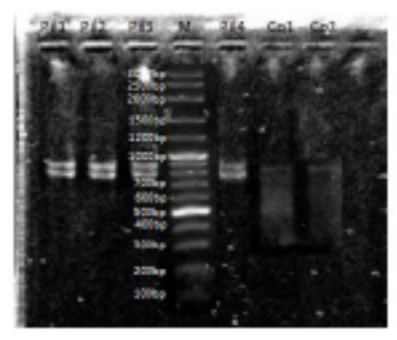

PII PLE P13 M PI4 Cot CoO
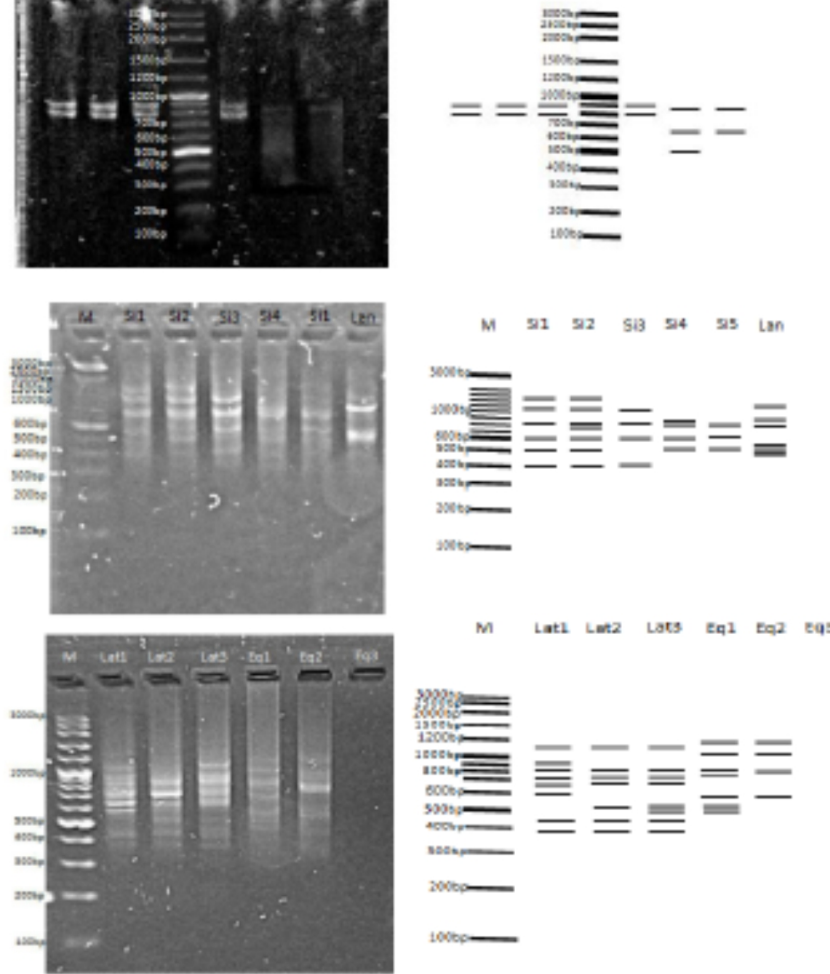

Gambar 4. Hasil elektroforesis sampel DNA Macrobrachium spp. yang diamplifikasi dengan primer ISSR3 (Keterangan: $\mathrm{M}=$ marker, $\mathrm{Pi}=M$. pilimanus, $\mathrm{Co}=M$. cowlesi, $\mathrm{Si}=M$. sintangense, $\mathrm{Lan}=M$. lanchesteri, Lat $=$ M. latidactylus, $\mathrm{Eq}=$ M. equidens). 
Gambar 3 dan 4 menunjukkan hasil elektroforesis amplifikasi sampel DNA Macrobrachium spp dari Sungai Opak, DIY menggunakan primer ISSR1 dan ISSR3.
Gambar 5 menunjukkan dendogram hasil analisis similaritas berdasarkan karakter molekular Macrobrachium spp. dari Sungai Opak DIY.

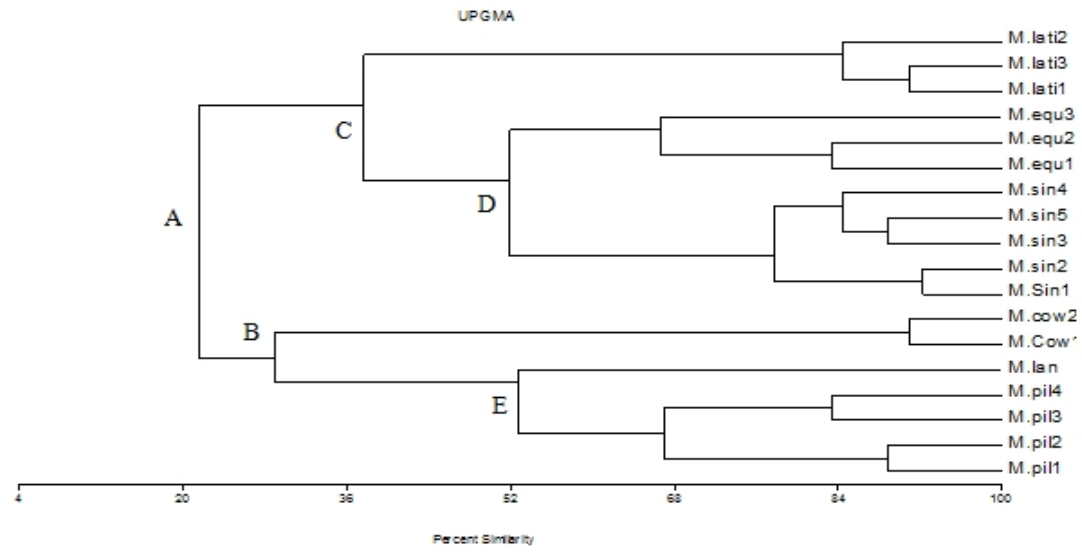

Gambar 5. Dendogram similaritas fenetik karakter molekular intraspesies dan interspesies Macrobrachium spp. dari Sungai Opak DIY (Ket: M. pil=M. pilimanus, M.sin=M. sintangense, M. cow $=M$. cowlesi, . lati=M. latidactylus, . lan=M. lanchesteri, . equ=M. equidens).

\section{PEMBAHASAN}

Keanekaragaman jenis udang di Sungai Opak. Macrobrachium sintangense memiliki kemelimpahan paling tinggi dan persebaran yang paling luas. Hal ini bersesuaian dengan kenyataan yang terjadi di Sungai Opak bahwasanya spesies ini dijumpai dari hulu TS2 hingga hilir TS5 karena bagian sungai tersebut berarus lambat dan cukup dalam sehingga habitat tersebut cocok untuk Macrobrachium sintangense. Macrobrachium pilimanus hanya dijumpai pada sungai bagian hulu TS 1 hingga TS 3 dan sungai bagian hilir TS 1. Jenis ini hidup pada habitat air sungai berarus deras dengan substrat pasir dan batuan. Hal ini dapat dibuktikan dengan fenomena yang terjadi di lapangan, bahwa pada stasiun hulu TS1-3 merupakan sungai yang berarus deras dengan substrat pasir dan batuan sehingga cocok sebagai tipe habitat $M$. pilimanus.

Macrobrachium equidens dan $M$. latidactylus merupakan spesies yang lebih menyukai hidup di perairan payau sehingga pada penelitian ini spesies tersebut hanya dijumpai di sungai bagian muara dengan kemelimpahan sebesar $1,5 \%$. Sementara $M$. cowlesi hanya dapat dijumpai di sungai bagian hilir TS 4 dan TS 5. Informasi mengenai jenis ini masih belum banyak diketahui (De Grave \& Wowor, 2013). Keberadaan spesies ini sangat sedikit yaitu hanya ditemukan 2 individu. Karakter habitat tempat ditemukannya spesies tersebut berupa sungai yang dalam dengan batu-batu besar dan tanaman eceng gondok serta merupakan titik pertemuan antara Sungai Opak dengan Sungai Oya. Spesies ini juga ditemukan di bagian sungai yang sangat dekat dengan muara dan terdapat bendungan.

Spesies udang yang memiliki kemelimpahan paling sedikit adalah $M$. lanchesteri yang hanya ditemukan 1 individu dari seluruh total titik sampling yaitu di TS 1 Sungai Opak bagian hilir. Spesies ini bukanlah spesies asli Indonesia, namun merupakan spesies introduksi dari Thailand. Berdasarkan hasil penelitian ini menunjukkan bahwa keanekaragaman jenis udang di Sungai Opak DIY dipengaruhi oleh ketinggian tempat dan karakteristik habitat. Beberapa titik sampling berarus deras dan dalam sehingga tidak memungkinkan untuk mengambil sampel di bagian tengah badan sungai dengan peralatan sampling berupa seser dan jala tebar.

Karakter morfologis Macrobrachium spp di Sungai Opak. Cluster $\mathrm{C}$ terdiri dari $M$. lanchesteri dan $M$. equidens yang merupakan 
kelompok udang yang memiliki pereiopod kedua yang halus atau tanpa rambut-rambut yang lebat. Selain memiliki kemiripan dalam hal bentuk pereiopod, individu-individu yang diperoleh saat sampling dari kedua spesies ini masih juvenil. Bagian-bagian tubuh tertentu yang penting untuk identifikasi pada individu yang masih juvenil seringkali belum tumbuh, sehingga dari hasil pengamatan morfologis, pengukuran morfometri maupun perhitungan meristik menyebabkan kedua spesies ini memiliki kemiripan yang tinggi. Kedua spesies tersebut mengelompok dengan koefisien 0,618 (kesamaan 61,8\%). M. equidens memiliki kemiripan intraspesies sebesar 73,6\%. Cluster B terdiri dari M. pilimanus, $M$. sintangense, $M$. cowlesi, dan $M$. latidactylus. Tiga spesies pertama merupakan kelompok udang yang memiliki kaki dengan rambut-rambut yang lebat atau pubescene. Sedangkan $M$. latidactylus merupakan jenis udang yang tidak memiliki rambut-rambut lebat pada pereiopod. Dalam dendogram ini (Gambar 1), $M$. latidactylus memiliki kemiripan yang paling tinggi dengan $M$. cowlesi, hal ini disebabkan kedua spesies ini sama-sama memiliki pasangan pereiopod kedua yang berbeda bentuk maupun ukuran. Selain itu, kedua spesies ini memiliki habitat yang cukup dekat yaitu pada bagian hilir dan muara sungai.

Cluster $B$ memisahkan $M$. latidactylus yang merupakan udang air payau dengan cluster D (kelompok udang dengan habitat air tawar) dengan koefisien 0,612 (kesamaan 61,2\%). Cluster D memisahkan M. cowlesi (udang dengan habitat di sungai bagian hilir) dengan Cluster E (kelompok udang dengan habitat di sungai bagian hulu dan tengah) dengan koefisien 0,623 (kesamaan 62,3\%). Cluster $E$ terdiri dari kelompok jenis $M$. sintangense dan $M$. pilimanus yang keduanya memiliki kemiripan dengan koefisien 0,698 (kesamaan 69,8\%). Bila dilihat dari segi morfologis, $M$. sintangense memiliki karakter morfologis yang sangat mirip dengan $M$. lanchesteri, sehingga dalam dendogram ini seharusnya $M$. sintangense lebih dekat dengan $M$. lanchesteri, namun karena $M$. lanchesteri yang ditemukan saat sampling masih juvenil menyebabkan kedua spesies ini tidak menunjukkan kemiripan dalam dendogram. $M$. sintangense menunjukkan kemiripan yang lebih tinggi dengan $M$. pilimanus karena kedua spesies ini sama-sama memiliki pasangan pereiopod kedua yang sama bentuk dan dilengkapi dengan pubescene. Indeks similaritas intraspesies tertinggi dimiliki oleh kelompok $M$. cowlesi yaitu sebesar $86,5 \%$, diikuti oleh $M$. latidactylus, $M$. sintangense, $M$. pilimanus, dan $M$. equidens secara berturut-turut sebesar $85,5 \%, 82,2 \%, 74 \%$ dan $73,6 \%$. Indeks similaritas intraspesies yang tinggi menunjukkan bahwa variasi morfologis antar individu dalam spesies tersebut rendah, sedangkan similaritas intraspesies yang rendah menunjukkan bahwa variasi morfologis antar individu dalam spesies tersebut tinggi. Variasi morfologis intraspesies yang tinggi memungkinkan spesies tersebut memiliki daya survive yang tinggi terhadap variasi perubahan lingkungan habitatnya.

Karakter molekular Macrobrachium spp. di Sungai Opak. Berdasarkan Tabel 2, dapat dilihat bahwa kedua primer yang digunakan menunjukkan polimorfisme yang tinggi yaitu $100 \%$. Hal ini menunjukkan bahwa primer ISSR1 dan ISSR3 dapat mendeteksi variasi genetik antar jenis pada udang air tawar terutama genus Macrobrachium. Jumlah lokus polimorfik dalam analisis variasi genetik menentukan tingkat variasi genetik intra maupun interspesies, jika jumlah lokus polimorfik banyak maka tingkat variasi genetik juga akan tinggi.

Total lokus yang dihasilkan dari tiap spesies yang diamplifikasi dengan menggunakan kedua primer sangat bervariasi. Hal ini berhubungan dengan proses pengenalan primer terhadap sekuen homolognya pada DNA template, karena tiap individu memiliki perbedaan panjang situs DNA yang dapat diamplifikasi oleh primer. Selain itu, jumlah lokus yang dihasilkan juga dipengaruhi oleh jumlah sampel tiap individu yang diamplifikasi.

Polimorfisme yang dihasilkan dari tiap spesies juga bervariasi, persentase polimorfik intraspesies paling tinggi dihasilkan oleh $M$. pilimanus yaitu sebesar $70 \%$, sedangkan 
presentase polimorfik paling rendah dihasilkan oleh $M$. cowlesi yaitu sebesar 44,44\% (Tabel 3). Hal ini menunjukkan bahwa M. pilimanus memiliki keragaman genetik yang lebih tinggi dibandingkan species lain. Keragaman genetik mempunyai arti penting dalam stabilitas dan ketahanan populasi seperti pencegahan terhadap kehilangan fitness individu yang disebabkan oleh inbreeding yang dapat mengakibatkan kepunahan karena sifat yang seragam. Keragaman genetik yang rendah akan berakibat negatif terhadap sifat penting dalam makhluk hidup seperti kecilnya kelangsungan hidup suatu organisme, berkurangnya pertumbuhan dan keragaman ukuran serta turunnya kemampuan adaptasi. Hal ini disebabkan karena setiap gen memiliki respon yang berbeda-beda terhadap kondisi lingkungan, sehingga dengan dimilikinya berbagai macam gen dari individu-individu di dalam populasi maka berbagai perubahan lingkungan yang ada akan dapat direspon lebih baik.

Primer ISSR1 menunjukkan monomorfisme yang terjadi pada individuindividu dalam satu spesies (Gambar 3). Pitapita monomorfik intraspesies ini merupakan suatu lokus dengan ukuran tertentu yang dimiliki oleh semua individu dalam suatu spesies. M. pilimanus memiliki pita-pita yang monomorfik pada ukuran 806 bp. M. cowlesi memiliki pita-pita monomorfik yang lebih banyak yaitu dengan ukuran 806, 575, dan 537 bp. Lokus monomorfik juga ditemukan pada individu-individu $M$. sintangense pada ukuran 1227, 650 dan 300 bp. Spesies udang yang berhabitat muara, yaitu M. latidactylus dan $M$. equidens, keduanya memiliki lokus monomorfik dengan ukuran $600 \mathrm{bp}$. Individuindividu $M$. latidactylus yang dideteksi dengan primer ini juga memiliki lokus monomorfik dengan ukuran 400 dan 300 bp. Sementara populasi $M$. equidens memiliki lokus monomorfik lain di ukuran $465 \mathrm{bp}$.

Primer ISSR3 juga menunjukkan adanya lokus monomorfik intraspesies pada populasi udang Macrobrachium yang diteliti (Gambar 4). Primer ini menghasilkan 2 lokus pada $M$. pilimanus yang keseluruhannya adalah monomorfik pada ukuran 900 dan 800 bp.
Sedangkan pada $M$. cowlesi dijumpai adanya lokus monomorfik pada ukuran 840 dan 626 bp.

Lokus monomorfik dengan ukuran 800 dan 600 bp ditemukan pada populasi udang $M$. sintangense. Pita DNA dengan ukuran $800 \mathrm{bp}$ juga ditemukan pada $M$. lanchesteri yang secara morfologis sulit dibedakan dengan $M$. sintangense. Populasi udang muaramemiliki lokus monomorfik 1094, 800, 700, dan 440 bp untuk M. latidactylus, sedangkan M. equidens pada ukuran 1154,1000 , dan 576 bp.

Gambar 5 menunjukkan similaritas berdasarkan karakter molekular seluruh sampel Macrobrachium spp. Berdasarkan dendogram tersebut dapat diketahui bahwa sampel yang diamati membentuk dua cluster besar, yaitu cluster $\mathrm{B}$ dan $\mathrm{C}$ dengan koefisien similaritas $21,52 \%$. Pola pengelompokan ini lebih cenderung berdasar dari perbedaan ukuran telur, tipe perkembangan larva serta persamaan karakter morfologis udang. Wowor et al. (2009) menyebutkan bahwa nenek moyang udang Macrobrachium di Asia memiliki ukuran telur yang kecil dan banyak serta memiliki perkembangan larva yang panjang dan membutuhkan air payau untuk perkembangan larvanya. Udang Macrobrachium yang memiliki ukuran telur yang besar dan berjumlah sedikit memiliki perkembangan larva yang pendek serta tidak memerlukan air payau untuk perkembangan larvanya.

Pada Cluster E terdapat M. pilimanus dan $M$. lanchesteri yang memiliki koefisien similaritas $52,77 \%$. Kedua spesies ini merupakan kelompok udang yang memiliki perkembangan larva yang pendek dan tidak memerlukan air payau untuk perkembangan larvanya. M. pilimanus memiliki ukuran telur yang besar sedangkan $M$. lanchesteri memiliki ukuran telur sedang. Cluster $E$ menyatu dengan $M$. cowlesi pada cluster $B$ dengan koefisien similaritas $29,11 \%$. M. cowlesi merupakan udang yang membutuhkan air payau untuk perkembangan larvanya. Namun, pada dendogram ini $M$. cowlesi memiliki kemiripan yang lebih tinggi dengan $M$. lanchesteri dan M. pilimanus daripada dengan $M$. latidactylus dan $M$. equidens yang 
kehidupan larvanya berada di air payau. Hal ini mungkin disebabkan karena $M$. cowlesi secara morfologis mirip dengan $M$. pilimanus, yaitu memiliki pasangan pereiopod kedua yang pendek dan gemuk. Cluster $C$ terdiri dari udang dengan struktur kaki yang langsing dan panjang. $M$. sintangense menghabiskan seluruh perkembangan larvanya di air tawar sehingga perkembangan larvanya pendek dan memiliki telur yang berukuran sedang. Sedangkan $M$. latidactylus dan $M$. equidens memiliki telur yang berukuran kecil dan banyak serta perkembangan larvanya panjang. Namun hasil yang ditunjukkan dari dendogram, $M$. equidens lebih menyatu dengan $M$. sintangense. Hal ini mungkin dikarenakan kedua spesies ini sama-sama memiliki pasangan pereiopod kedua yang sama bentuk maupun ukurannya.Kedua spesies ini mengelompok pada cluster $D$ dengan koefisien similaritas 51,88\%. Kemudian $M$. latidactylus dan cluster $D$ menyatu pada cluster $C$ dengan koefisien similaritas 37,67\%.

Similaritas intraspesies secara berturutturut, dari yang paling tinggi hingga yang paling rendah, dimiliki oleh $M$. cowlesi (90,9\%), M. latidactylus (84,44\%), $\quad$ M. sintangense $(77,72 \%)$, M. pilimanus $(66,97 \%)$ dan $M$. equidens $(66,66 \%)$.

Hasil analisis similaritas fenetik berdasarkan karakter morfologis dan molekular melalui dendogram terlihat bahwa similaritas udang Macrobrachium spp. di Sungai Opak DIY dipengaruhi oleh struktur morfologis pereiopod kedua, tipe habitat, ukuran dan jumlah telur, serta tipe perkembangan larva. Dari keenam jenis udang yang diperoleh, nampak pada kedua dendogram bahwa $M$. pilimanus yang merupakan udang yang berhabitat di sungai bagian hulu selalu terletak saling berjauhan dengan kelompok udang yang ditemukan di muara (M. latidactylus dan M. equidens). Hal ini menguatkan pendapat Wowor et al. (2009) yang mengatakan bahwa udang dengan perkembangan larva yang panjang merupakan common ancestor udang Macrobrachium spp. di Asia, sedangkan Macrobrachium yang sukses berevolusi hanya memerlukan air tawar untuk meyelesaikan siklus perkembangan larvanya yang pendek.

\section{KESIMPULAN}

Penelitian ini memperoleh 6 jenis udang Macrobrachium di Sungai Opak DIY ( $M$. pilimanus, $M$. sintangense, $M$. lanchesteri, $M$. cowlesi, M. latidactylus, dan $M$. equidens). Persentase similaritas fenetik berdasarkan karakter morfologi, morfometri, dan meristik menunjukkan indeks similaritas secara berturut-turut dari tertinggi hingga terendah dimiliki oleh $M$. cowlesi (86,5\%), $M$. latidactylus $(85,8 \%)$, M. sintangense (82,2\%), M. pilimanus (74\%), dan M. equidens $(73,6 \%)$. Keseluruhan sampel memiliki indeks similaritas dengan koefisien 55,6\%. Persentase similaritas fenetik berdasarkan karakter molekular pada keseluruhan sampel berada pada koefisien $21,52 \%$. Indeks similaritas intraspesies dari yang tertinggi hingga terendah secara berturut-turut dimiliki oleh $M$. cowlesi $(90,9 \%)$, M. latidactylus $(84,44 \%), M$. sintangense $(77,72 \%)$, M. pilimanus $(66,97 \%)$ dan $M$. equidens $(66,66 \%)$. Hasil analisis similaritas fenetik berdasarkan karakter morfologis dan molekular melalui dendogram terlihat bahwa similaritas udang Macrobrachium spp. di Sungai Opak DIY dipengaruhi oleh struktur morfologis pereiopod kedua, tipe habitat, ukuran dan jumlah telur, serta tipe perkembangan larva.

Perlu dilakukan penelitian secara intensif pada musim yang berbeda untuk mendapatkan informasi keanekaragaman Macrobrachium spp. yang lebih lengkap. Penelitian molekular menggunakan marker gen mitokondria maupun gen inti (nuclear) dan metode analisis yang berbeda untuk mendapatkan hubungan kekerabatan antar spesies yang lebih akurat perlu dilakukan.

\section{UCAPAN TERIMA KASIH}

Penelitian ini dapat terlaksana atas bantuan dari Fakultas Biologi UGM dan PPKB UGM yang telah memberikan dana penelitian melalui Dana BOPTN 2013 kepada Rury Eprilurahman dan Dana PPKB UGM 2013 kepada Anita Widianawati. Penulis menyampaikan terima kasih kepada Tim 
peneliti Sungai Opak yang telah banyak memberikan waktu baik di lapangan maupun di laboratorium dan Dr. Ir. Daisy Wowor, M.Sc. (Peneliti Crustacea LIPI) atas bantuan, diskusi dan bimbingannya dalam identifikasi spesimen Macrobrachium spp. dari Sungai Opak.

\section{DAFTARPUSTAKA}

De Grave S. and Wowor D. 2013. Macrobrachium cowlesi. In: IUCN 2013. IUCN Red List of Threatened Spesies. $\quad$ Version 2013.1. http://www.iucnredlist.org. Diakses 05 November 2013.

Eguia MRR, Dejarme HE, Rosario WR, Roxas EC, and Wowor D. 2009. Philippine freshwater prawns (Macrobrachium spp.). Aquaculture Extension Manual. vol 43:50.
Taufik. 2011. Keanekaragaman Udang Air Tawar di Danau Kerinci Provinsi Jambi [Tesis]. Bogor: Fakultas Matematika dan Ilmu Pengetahuan Alam. Institut Pertanian Bogor.

Trijoko dan Pranoto FS. 2006. Keanekaragaman Jenis Ikan di Sepanjang Aliran Sungai Opak Daerah Istimewa Yogyakarta. Prosiding Seminar Nasional Ikan IV. 29-30 Agustus 2006. Jatiluhur. hal. 293-300.

Wowor D, Muthu V, Meier R, Balke M, Cai Y, and $\mathrm{Ng}$ PKL. 2009. Evolution of Life History Traits in Asian Freshwater Prawns of Genus Macrobrachium (Crustacea: Decapoda: Palaemonidae) Based On Multilocus Molecular Phylogenetic Analysis. Molecular, Phylogenetic and Evolution. vol 52: 340-35. 